Jurnal Teknologi, 37(C) Dis. 2002: 11-20

(C) Universiti Teknologi Malaysia

\title{
STUDY OF FRACTAL BOND CONNECTIVITY OF NEODYMIUM PHOSPHATE GLASSES BY ULTRASONIC TECHNIQUE
}

\author{
AGUS SETYO BUDI ${ }^{1}$, ROSLI HUSSIN ${ }^{2} \&$ MD. RAHIM SAHAR ${ }^{3}$
}

\begin{abstract}
The elastic properties of neodymium phosphate $\mathrm{xNd}_{2} \mathrm{O}_{3}(1-\mathrm{x}) \mathrm{P}_{2} \mathrm{O}_{5}$ glasses with different compositions containing from 10 to $25 \mathrm{~mole} \% \mathrm{Nd}_{2} \mathrm{O}_{3}$ has been studied by ultrasonic technique, as functions of temperature from $270 \mathrm{~K}$ to $303 \mathrm{~K}$. The elastic properties like adiabatic elastic stiffness coefficients, $\mathrm{C}_{11}, \mathrm{C}_{44}$ and bulk modulus, $\mathrm{B}$ of the glasses have been determined using the experimental data. The temperature dependence of the elastic properties were used to explores useful information about the fractal bond connectivity of the neodymium phosphate glasses which lies between 2.00 and 2.70. This result indicates that the neodymium phosphate glasses were connected in an array between two and three dimensional network.
\end{abstract}

Key words: elastic properties, neodymium phosphate glasses, ultrasonic studies

\begin{abstract}
Abstrak. Sifat-sifat kenyal untuk kaca neodimium fosfat $\mathrm{xNd}_{2} \mathrm{O}_{3}(1-\mathrm{x}) \mathrm{P}_{2} \mathrm{O}_{5}$ dengan komposisi yang berbeza dari 10 hingga $25 \% \mathrm{~mol} \mathrm{Nd}_{2} \mathrm{O}_{3}$, telah dikaji melalui kaedah ultrasonik, sebagai fungsi suhu dari $270 \mathrm{~K}$ hingga $303 \mathrm{~K}$. Sifat-sifat kenyal yang dikaji antaranya ialah pemalar kekenyalan adiabatik $\mathrm{C}_{11}, \mathrm{C}_{44}$ dan modulus pukal, $\mathrm{B}$ yang telah diperolehi dari data pengukuran eksperimen. Dalam kajian ini menunjukkan bahawa sifat-sifat kenyal bersandar kepada suhu dan seterusnya memberi maklumat tentang hubungan ikatan fraktal bagi kaca neodimium fosfat yang terletak di antara 2.00 hingga 2.70. Keputusan dari kajian ini menunjukkan bahawa kaca neodimium fosfat mempunyai struktur yang tersusun dalam rangkaian di antara dua dan tiga dimensi.
\end{abstract}

Kata kunci: sifat kenyal, kaca neodimium fosfat, kajian ultrasonik

\subsection{INTRODUCTION}

In glass science, interest in glasses based on $\mathrm{P}_{2} \mathrm{O}_{5}$ has been stimulated by some properties and crystallization behaviour that are unique to phosphate glasses [1]. These facts make them candidates for a variety of specialty applications such as hermetic seals, rare-earth ion hosts for solid state lasers, fast-ion conductors or biomedical material [2]. Besides phosphate-containing biocompatible glass-ceramics, vitreous bone implants have received attention in recent years. Metaphosphate glasses containing rare-earth ions have potentially important applications in optical communications and laser technologies [3,4]. Glasses of the $\left[\mathrm{R}_{2} \mathrm{O}_{3}\right]_{\mathrm{x}}\left(\mathrm{P}_{2} \mathrm{O}_{5}\right]_{(1-\mathrm{x})}$ formula (where $\mathrm{R}$ represents one of the lanthanide ions) have been reported to exhibit the largest magnetic contributions to the low temperature specific heats known in oxide glasses [5]. Sm and Eu phosphate

$\overline{1,2 \& 3}$ Jabatan Fizik, Fakulti Sains, Universiti Teknologi Malaysia, 81310 Skudai, Johor. 
glasses are unusual in having a negative hydrostatic pressure dependence of bulk modulus and a negative coefficient of thermal expansion [6]. The promising physical properties of the rare-earth phosphate glasses have initiated many studies of their structure using various techniques including EXAF, X-ray, neutron diffraction, Raman scattering and Mössbauer spectroscopy.

Strength is usually not the primary physical property of an oxide glass that determines its choice as a desirable material for a given use. In addition, because the practical strength of a glass is often controlled by surface damage, it has been felt that the measurement of intrinsic strength is not pertinent. Thus, in spite of the very large number of studies which have been made on the tensile strength of oxide glasses over the years, an understanding of their properties is incomplete. Very little information to our knowledge about variations in the mechanical properties, in particular 'intrinsic strength', as a function of glass composition and/or structure is available. Therefore, a more complete understanding must be developed, however. It is useful to measure strength and structure in order to more completely understand both.

The phosphate network is made of corner-sharing $\mathrm{PO}_{4}$ tetrahedral units that can be classified according to their connectivity, $Q^{n}$, where $n$ is the number of bridging oxygen per tetrahedron [7]. The polymerisation degree of the phosphate network decreases with modifier addition and also depends on the nature of the counter ions. The networks of phosphate glasses can be classified by the oxygen-to-phosphorus ratio $(\mathrm{O} / \mathrm{P})$, which sets the number of linkages through bridging oxygens to neighboring P-tetrahedra. Thus, metaphosphate $(\mathrm{O} / \mathrm{P}=3)$ and polyphosphate $(\mathrm{O} / \mathrm{P}>3)$ glasses consist structures that are based on chain-like phosphate anions and interconnected through terminal oxygens by ionic bonds with modifying cations. $Q^{2}$ tetrahedra form the links within the chains and $Q^{1}$ tetrahedra terminate the chains. The chain length of the average phosphate anion decreases with increasing $\mathrm{O} / \mathrm{P}$. Ultraphosphate $(\mathrm{O} / \mathrm{P}<3)$ glasses have networks that are cross-linked by $\mathrm{Q}^{3}$ tetrahedra. As the modifier content is increased, there is a reduction of the number of cross-linking P-O-P bond between pairs of tetrahedra and a tendency toward an increase in the number of chains of $\mathrm{PO}_{4}$ tetrahedra in the structure.

Ultrasonic technique is a versatile tool for investigating the changes in microstructure, deformation process and mechnical properties of material and components [8]. It is due to the fact that, the ultrasonic waves are closely related with the elastic and inelastic properties of the materials. The increased utilisation of this technique is due to the availability of different frequency ranges and many modes of vibration of the ultrasonic waves to probe into the macro, micro and submicropic levels.

In an amorphous solid (such as glass), elastic strain produced by a small stress can be described by two independent elastic constants, $\mathrm{C}_{11}$, longitudinal elastic constant and $\mathrm{C}_{44}$, shear elastic constant. For pure longitudinal waves, $C_{11}=\rho v_{\mathrm{L}}^{2}$, and for pure transverse waves $C_{44}=\rho v_{\mathrm{T}}^{2}$, where $v_{\mathrm{L}}$ and $v_{\mathrm{T}}$ are the longitudinal and transverse velocities respectively. The sound velocities also allow the determination of bulk 
modulus, $B$ by the equation $B=\rho\left(3 v_{\mathrm{L}}^{2}-4 v_{\mathrm{T}}^{2}\right) / 3$. The elastic stiffness depends upon the bonding in the glass and can be used to provide useful information about the network. The parameter relating the elastic properties of glasses to their network structure is fractal bond connectivity $d=4 \mathrm{C}_{44} / \mathrm{B}$ [9], where $B$ is the bulk modulus, which Bogue and Sladek [10] suggested should vary from $d=3$ for $3 \mathrm{D}$ networks of tetrahedral coordination polyhedra to $d=2$ for $2 \mathrm{D}$ structures and to $d=1$ for 1D chains.

This work is a part of our ongoing program to study the structure and properties of the rare-earth phosphate glasses. Herein the elastic properties of $\mathrm{Nd}_{2} \mathrm{O}_{3}-\mathrm{P}_{2} \mathrm{O}_{5}$ glasses were studied by means of ultrasonic technique, to obtain the value of fractal bond connectivity.

\subsection{EXPERIMENTAL PROCEDURES}

\subsection{Sample Preparation}

Neodymium phosphate glasses of general formula $\mathrm{xNd}_{2} \mathrm{O}_{3}-(1-\mathrm{x}) \mathrm{P}_{2} \mathrm{O}_{5}$ were prepared by melting mixtures of high-purity dry neodymium oxide with phosphorus pentoxide $\mathrm{P}_{2} \mathrm{O}_{5}$ in preweighed proportions in a closed platinum crucible of $80 \mathrm{~cm}^{3}$. Neodymium oxide and phosphorus pentoxide were mixed in a crucible, then was heated in an electrical furnace at a temperature which was progressively increased, reaching a maximum of approximately $1500^{\circ} \mathrm{C}$. To ensure proper mixing and homogeneity, the molten liquid was shaken frequently and vigorously. The melt was cast by pouring it as fast as possible into a $400^{\circ} \mathrm{C}$ hot steel split mould to quench it to form a glass. The glass was immediately transferred to an annealing furnace at $500^{\circ} \mathrm{C}$ where it was kept for 3 hours to relieve any residual stress which could cause embrittlement. At the end of this annealing process, the furnace was switched off and the glass was left to cool down to the room temperature gradually in a controlled cooling rate of $0.5^{\circ} \mathrm{C} / \mathrm{min}$. The castings were selectively cut, ground, and polished. After preparation, samples were stored in plastic containers in a dessicator.

\subsection{Ultrasonic Measurement}

The measurement of velocity of longitudinal and shear ultrasonic wave was performed at frequencies $10 \mathrm{MHz}$ and within the temperature range of 270 to $300 \mathrm{~K}$. A pulserreceiver card and the compatible software were used for the ultrasonic measurements. The temperature was controlled within $\pm 0.5^{\circ} \mathrm{C}$ of required temperature. The contribution to the loss due to the bonding agent between the transducer and the sample was neglected, because its typical thickness was lower than $10 \mu \mathrm{m}$. The estimated accuracies of the velocity measurements are 5\%. X- or Y-cut quartz transducers of frequency $10 \mathrm{MHz}$ were used for the generation of longitudinal and shear ultrasonic 
waves respectively. Nonaq stopcock grease was used to bond transducer to the specimen for the measurements of the longitudinal wave propagation throughout the entire range of temperature from 270 to $300 \mathrm{~K}$. The ultrasonic wave velocity was measured as a function of temperature using the pulse-echo-overlap techniques, which has a sensitivity of better than 1 part in $10^{5}$.

\subsection{RESULTS AND DISCUSSION}

The temperature dependences of the velocities of longitudinal and shear ultrasonic waves propagated in $\mathrm{xNd}_{2} \mathrm{O}_{3}(1-\mathrm{x}) \mathrm{P}_{2} \mathrm{O}_{5}$ ) glasses (with $\mathrm{x}$ equal to 0.10 and 0.25 ) were measured between 270 and $303 \mathrm{~K}$. The results of measurements are shown in Figure 1

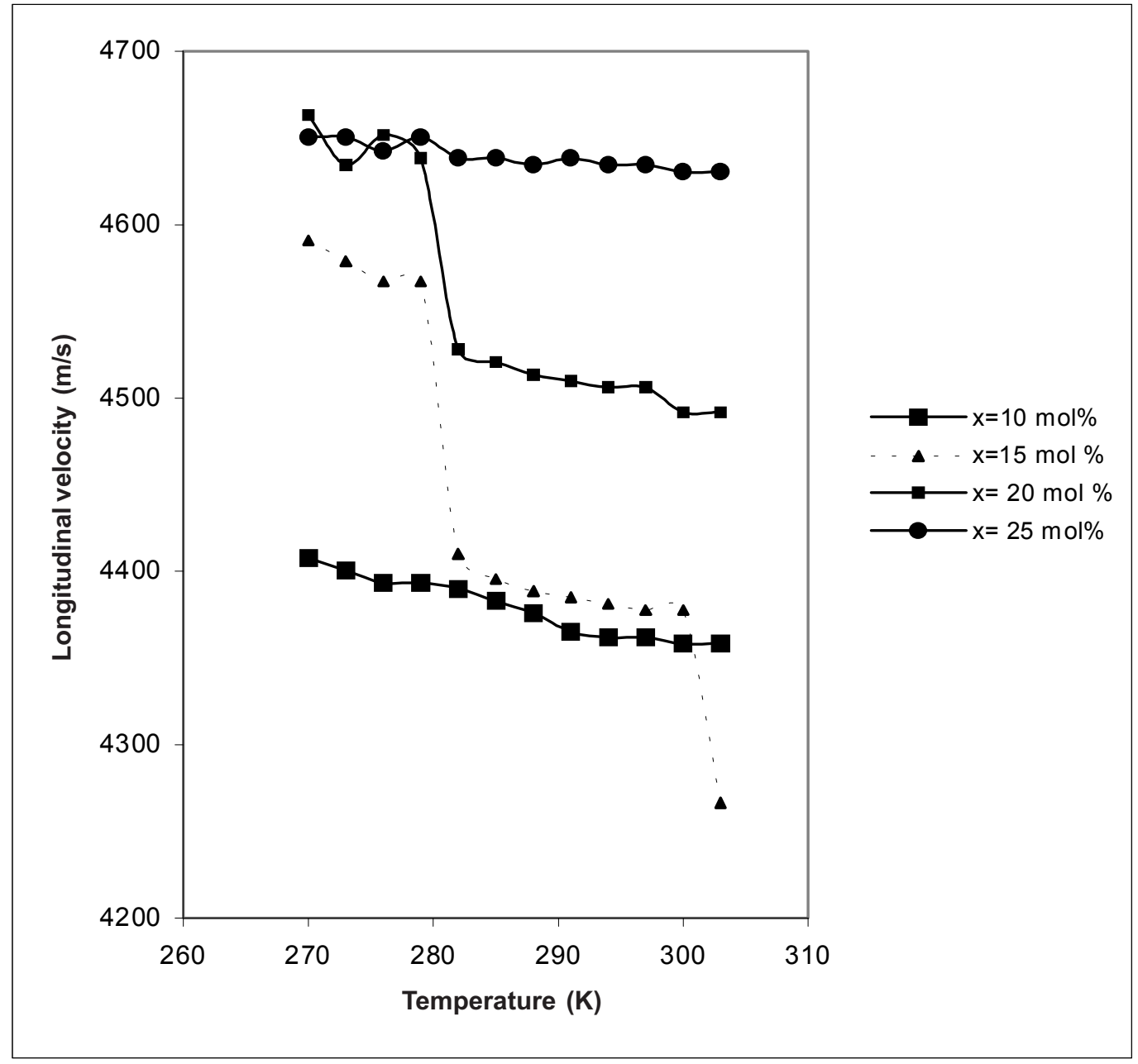

Figure 1 The temperature dependence of the longitudinal velocity of neodymium phosphate glasses, $\mathrm{xNd}_{2} \mathrm{O}_{3}(1-\mathrm{x}) \mathrm{P}_{2} \mathrm{O}_{5}$. The solid lines are fitted to aid the eye 


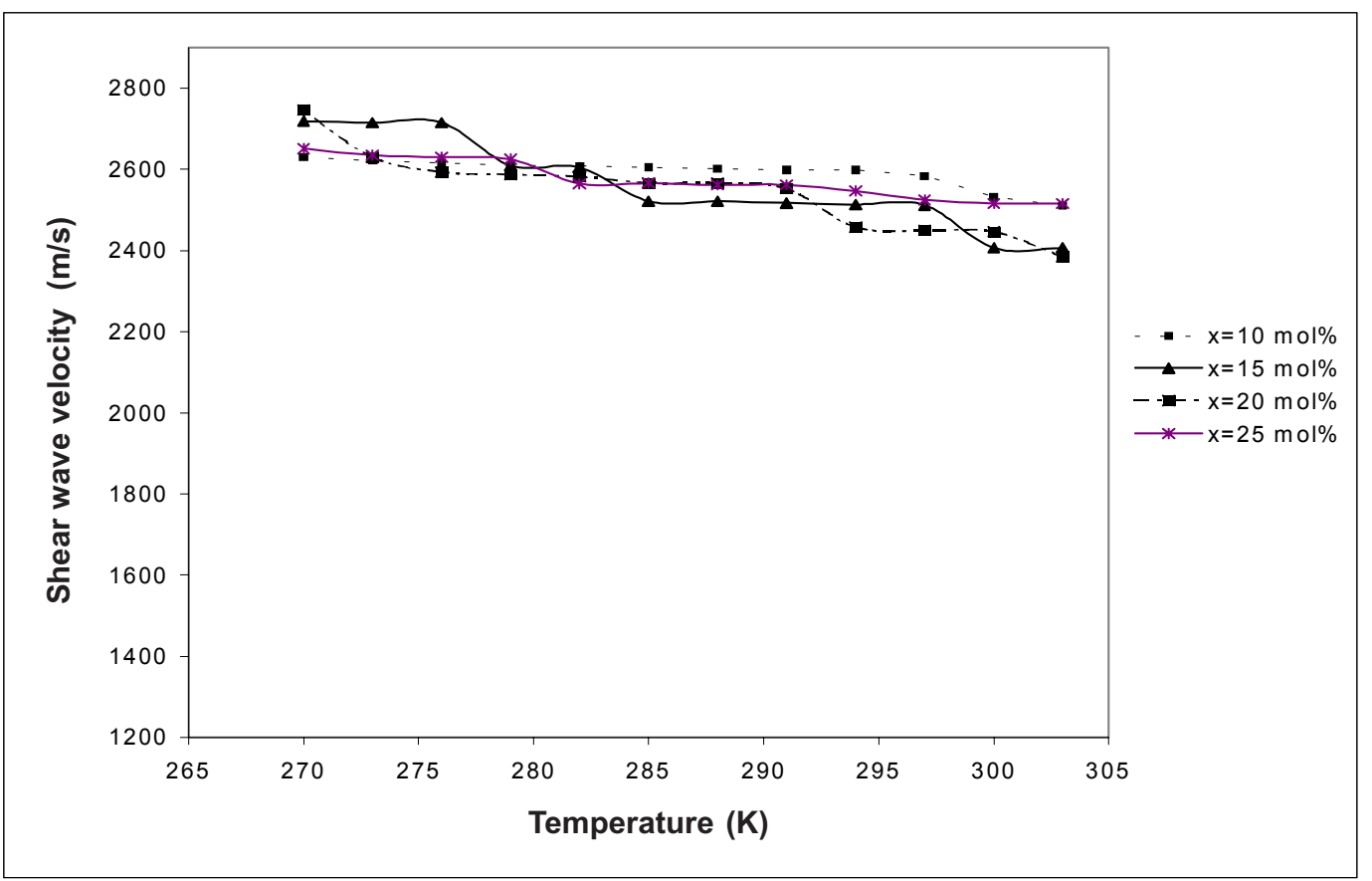

Figure 2 The temperature dependence of the shear wave velocities of neodymium phosphate glasses, $\mathrm{xNd}_{2} \mathrm{O}_{3}(1-\mathrm{x}) \mathrm{P}_{2} \mathrm{O}_{5}$. The solid lines are fitted to aid the eye

and 2. It is observed that the sound waves the ultrasonic velocity decreases slowly and monotonically with increasing temperature for all the samples. The variation of sound velocity has a small negative temperature coefficient. The measurements of ultrasonic velocity in neodymium phosphate glasses clearly indicate a dependence of ultrasonic wave velocities properties on temperature which differs from those of crystal. The low temperature properties have been attributed to low energy excitations which are present in amorphous materials. As would be expected for vitreous materials, the temperature dependences of the ultrasonic wave velocities do not conform to the behaviour usually observed in crystalline materials (corresponding to the effects of vibrational anharmonicity, namely, a linear increase of the ultrasonic wave velocity with decreasing temperature, terminating in a zero slope at low temperatures).

The measurements within the range of 270 to $303 \mathrm{~K}$ do not give any indication of a minimum in the variation of sound velocity with temperature. Thus, it appears that the variation of sound velocity with temperature in $\mathrm{Nd}_{2} \mathrm{O}_{3}-\mathrm{P}_{2} \mathrm{O}_{5}$ glasses does not resemble the behavior observed in many other glasses having tetrahedrally coordinated structures for which such a minimum always exists.

Studies on temperature dependence of the elastic moduli and acoustic velocity in phosphate glasses containing high concentration of samarium ions [11] and $\mathrm{Zn}\left(\mathrm{PO}_{3}\right)_{2}$ glass [12] clearly show such anomalies. The acoustic velocity as a function of temperature in $\mathrm{Zn}\left(\mathrm{PO}_{3}\right)_{2}$ glass has a minimum at about $200 \mathrm{~K}$, while in the case of $\mathrm{V}_{2} \mathrm{O}_{5}-\mathrm{P}_{2} \mathrm{O}_{5}$ 
glass such minimum has not been observed at least within the range from 77 to $300 \mathrm{~K}$ and the temperature coeficient of sound velocity is found to be negative throughout this range [13]. Temperature dependence of the acoustic velocity and attenuation for both longitudinal and transverse ultrasonic wave propagation within the temperature range $80-300 \mathrm{~K}$ has been interpreted in term of a thermally activated relaxation process [14]. This relaxation process comes into play when the ultrasonic wave disturbs the equilibrium of an atom moving in a double-well potential.

The calculated of elastic constants $\mathrm{C}_{11}, \mathrm{C}_{44}$ and bulk modulus $B$ from experimental results of neodymium phosphate glasses are presented in Figure 3 and 4 . The results shown that the elastic constant $\mathrm{C}_{11}$ and $\mathrm{C}_{44}$ decrease with increases in temperature, with the value of elastic constant $\mathrm{C}_{44}$ is smaller than value of elastic constant $\mathrm{C}_{11}$, as shown in Figure 3. The results indicate that neodymium phosphate glasses are easy to bend but difficult to compress. The bulk modulus for the $\mathrm{xNd}_{2} \mathrm{O}_{3}(1-\mathrm{x}) \mathrm{P}_{2} \mathrm{O}_{5}$ glasses increase monotonically up to about $303 \mathrm{~K}$, as shown in Figure 4. This results shown that the elasticity of the glass increases with the increase in mole $\%$ of $\mathrm{Nd}_{2} \mathrm{O}_{3}$. It is apparently that the stiffness of binary glasses decreases with the increase of content of $\mathrm{Nd}_{2} \mathrm{O}_{3}$.

The elastic constants $\left(\mathrm{C}_{11}\right.$ and $\left.\mathrm{C}_{44}\right)$ and bulk modulus $\mathrm{B}$ of the pure $\mathrm{P}_{2} \mathrm{O}_{5}$ glass are 41.4, 12.1 and 25.3 $\mathrm{GPa}$ respectively [15]. The measured elastic properties for a molybdenum phosphate glass are 40,12 and 22 Gpa respectively [16]. Comparison of these data with those of the neodymium phosphate glasses shows that the values of

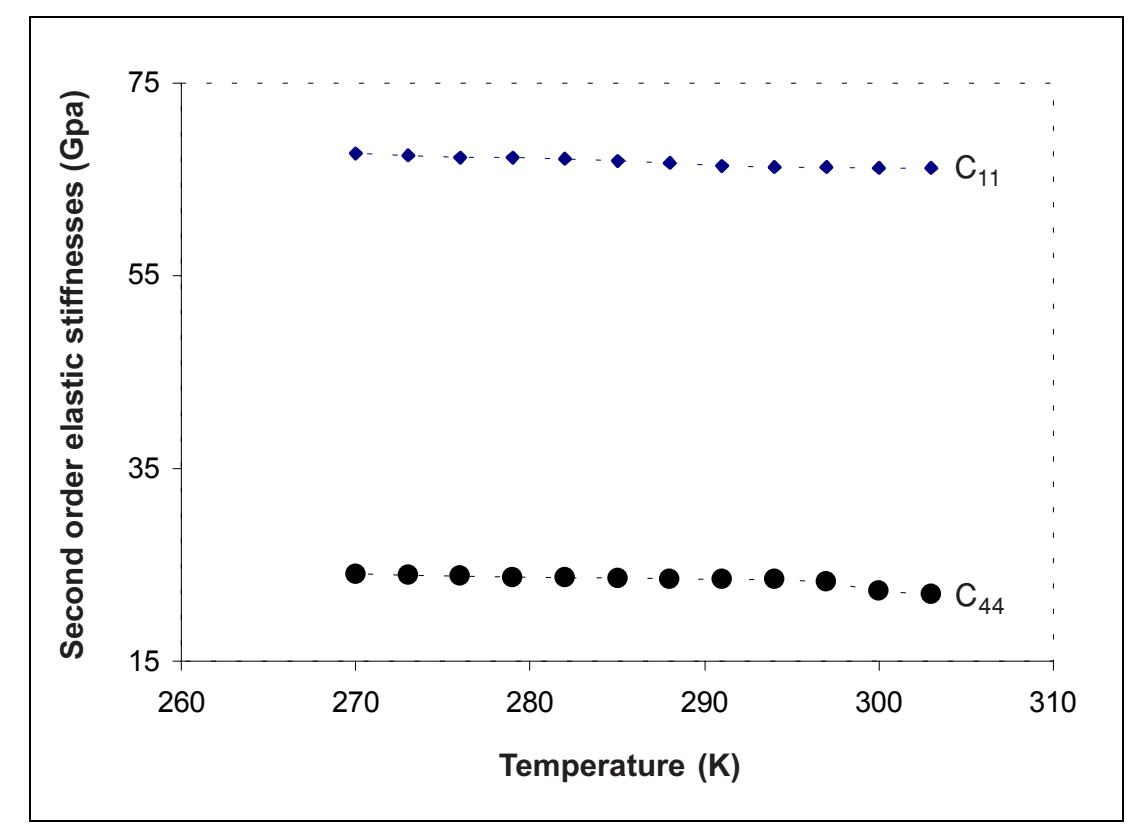

Figure 3 The temperature dependence of the second order elastic stiffness constants $\mathrm{C}_{11}$ and $\mathrm{C}_{44}$ for $10 \mathrm{~mol} \% \mathrm{Nd}_{2} \mathrm{O}_{3}$ phosphate glass sample 


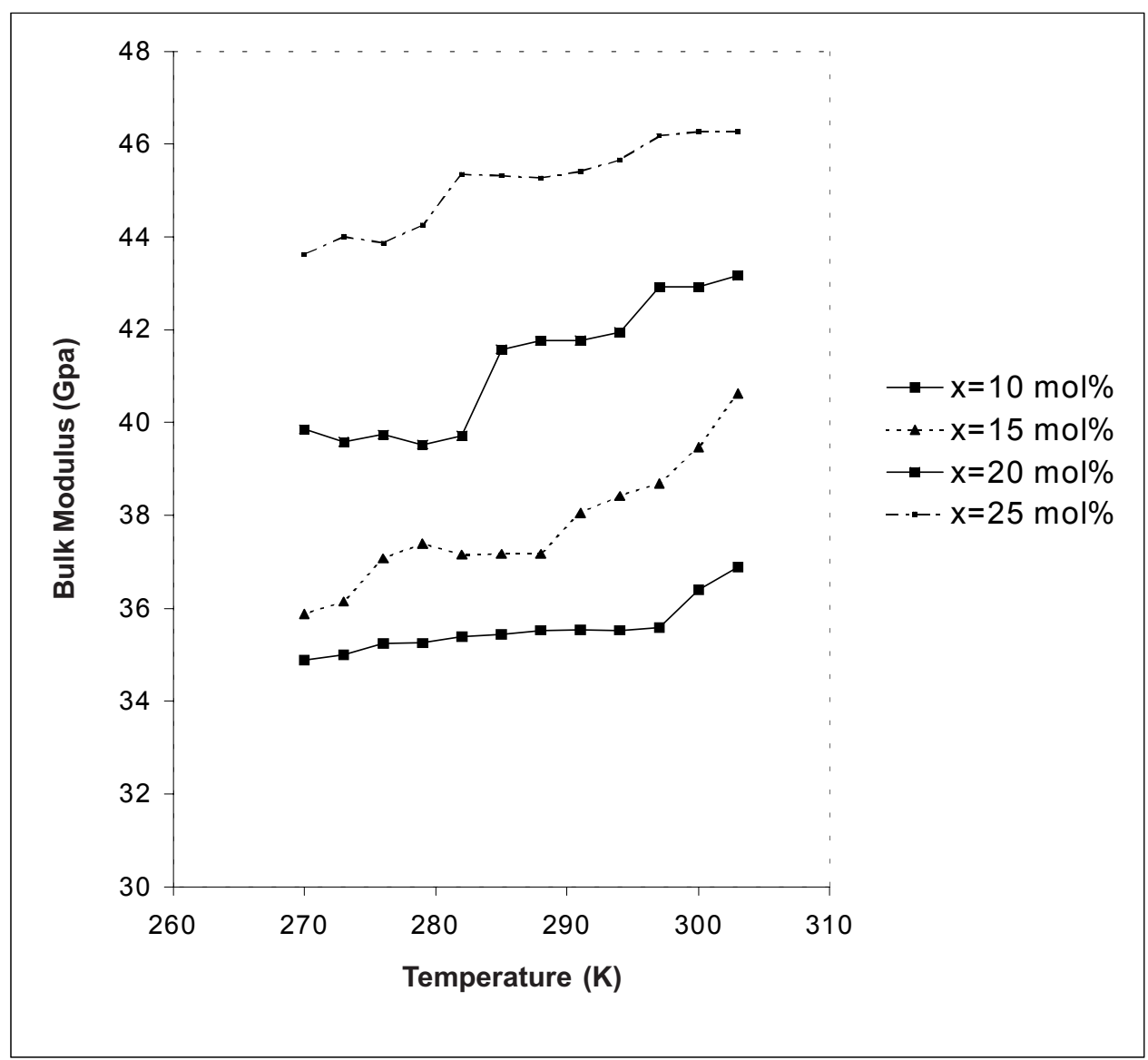

Figure 4 The temperature dependence of the bulk moduli of neodymium phosphate glasses, $\mathrm{xNd}_{2} \mathrm{O}_{3}(1-\mathrm{x}) \mathrm{P}_{2} \mathrm{O}_{5}$. The solid lines are fitted to aid the eye

elastic modulus is much higher. In order to explain the high value of elastic constants in neodymium phosphate glasses, the chain entanglement mechanism in alkali phosphate glasses with the structural modification by alkaline earth ions was used [17]. We may attempt to correlate the number of non-bridging oxygens with the charge of the modifier cations. To preserve the electric neutrality locally, neoydmium ions are paired with two non-bridging oxygens. Consequently, it leads to an enhancement in the strength of the structure and to an increase in the elastic moduli of the present glasses.

The shear to bulk modulus ratio of neodymium phosphate glasses at room temperature are shown in Figure 5. The $\mathrm{C}_{44} / \mathrm{B}$ tends to decrease with increasing $\mathrm{Nd}_{2} \mathrm{O}_{3}$ content is consistent with the loss or weakening of cross links between $\mathrm{PO}_{4}$ chains. It showed that the value of fractal bond connectivity, $d$ for neodymium phosphate glasses have connectivity between two and three dimensions. This value is similar to that found for the other rare earth metaphosphate glasses, implies a marked degree of 


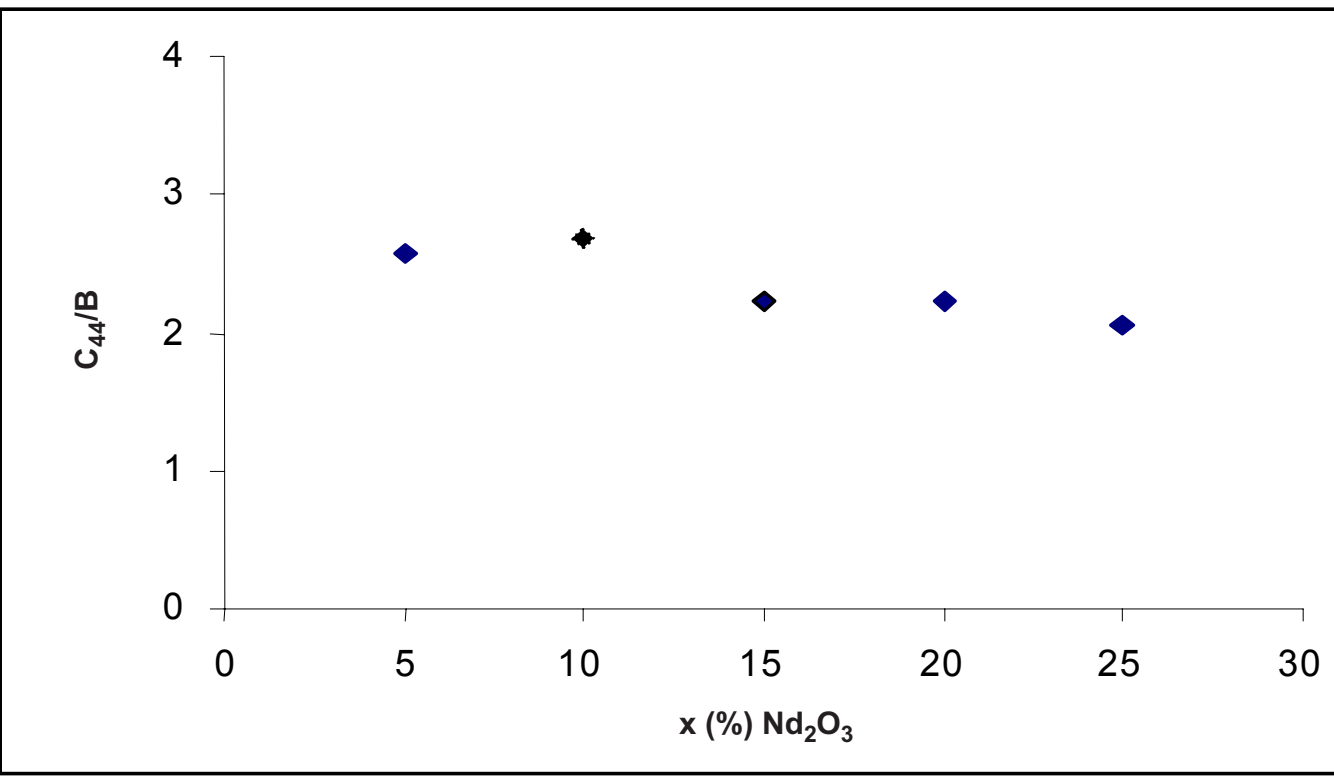

Figure 5 The shear-to bulk modulus ratio of $\mathrm{xNd}_{2} \mathrm{O}_{3}(1-\mathrm{x}) \mathrm{P}_{2} \mathrm{O}_{5}$ glasses at room temperature

cross-linkage, as would be anticipated for modifier cations whose valence is greater than unity, or increased branching of the network of $\mathrm{PO}_{4}$ chains facilitated by an increase in the number of end and branching units incorporated into the basic phosphate network. This is in accord with the coordination numbers found for rare earth metaphosphate glasses from the EXAFS studies [18-23].

\subsection{CONCLUSIONS}

Some of mechanical properties of neodymium phosphate glass with composition of $\mathrm{xNd}_{2} \mathrm{O}_{3}(1-\mathrm{x}) \mathrm{P}_{2} \mathrm{O}_{5}$, where $\mathrm{x}$ from 10 to 25 mole $\%$ have been measured using ultrasonic technique as functions of temperature from $270 \mathrm{~K}$ to $303 \mathrm{~K}$. The mechanism of chain entanglement effects of $\mathrm{PO}_{2}$ groups and the reduction of non-bridging oxygens by the modified rare earth cations seem to play significant roles to enhance the strength of our glasses as presented in our experimental observations of high values of elastic moduli. The decrease of fractal bond with increasing $\mathrm{Nd}_{2} \mathrm{O}_{3}$ content is consistent with the loss or weakening of cross links connectivity between $\mathrm{PO}_{4}$ chains. The fractal bond connectivity of neodymium phosphate glasses lies between 2.00 and 2.70 . This result indicates that the phosphate is connected in an array between two and three dimensional network. 


\section{ACKNOWLEDGEMENTS}

We wish to thank the IRPA (vot no. 72153) for research facility and for the provision of studentship (ASB). The authors express their sincere thanks to Mr. Jaafar Raji and Mr. Johari Zainudin for assistance in obtaining the data.

\section{REFERENCES}

[1] Abe Y., and H. Hosono. 1989. In: T. Kanazawa, (Editor), Inorganic Phosphate Materials, Materials Science Monographs. vol. 52. Amsterdam: Elsevier, 247.

[2] Brow R. K. 2000. J. Non-Cryst. Solids. 1: 263\&264.

[3] Durville F. M., E. G. Behrens, and R. C. Powell. 1986. Phys. Rev. B. 34: 4213.

[4] Broer M. M., A. J. Bruce, and W. H. Grodkiewicz. 1992. Phys. Rev. B. 45: 7077.

[5] Carini G., G. D’ Angelo, G. Tripodo, A. Bartolotta, A. Fontana, F. Rossi, and G. A. Saunders. 1998. Philos. Mag. B. 77: 449.

[6] Farok H. M., H. B. Senin, G. A. Saunders, W. Poon, and H. Vass. 1994. J. Mater. Sci. 29: 2847.

[7] Carini G., G. D’Angelo, M. Federico, and G. Tripodo. 1994. Phys. Rev. B. 50: 2858-2864.

[8] Krauthramer J., and H. Krauthramer. 1993. Ultrasonic Testing of Materials. $4^{\text {th }}$ edn., New Delhi: Narosha Publishing Company.

[9] Saunders G. A, T. Brennan, M. Acet, and M. Cankurtaran. 2001. J. Non Cryst. Solids. 282: 291.

[10] Bogue R., and R. J. Sladek. 1990. Phys. Rev. B. 42(8): 5280.

[11] Mierzejewski A., G. A. Saunders, H. A. A. Sidek, and B. Bridge. 1988. J. Non Cryst. Solids. 104: 323.

[12] Krause J. T., and C. R. Kurkjian. 1968. J. Am. Ceram. Soc. 51: 226.

[13] Mukherjee S., C. Basu, and U. S. Ghosh. 1992. J. Non Cryst. Solids. 144: 159.

[14] Anderson O. L., and H. E. Bommel. 1955. J. Am. Ceram. Soc. 38: 125.

[15] Bridge B., N. D. Patel, and D. N. Waters. 1983. Phys. Stat. Sol. A. 77: 655.

[16] Patel N. D., B. Bridge, and D. N. Waters. 1983. Phys. Chem. Glasses. 24: 122.

[17] Hudgens J.J., and S. W. Martin. 1993. J. Am. Ceram. Soc. 76: 1691.

[18] Bowron D. T., R. J. Newport, B. D. Rainford, G. A. Saunders, and H. B. Senin. 1995. Phys. Rev. B. 51: 5739.

[19] Bowron D., G. A. Saunders, R. J. Newport, B. D. Rainford, and H. B. Senin. 1996. Phys. Rev. B. 53: 5268.

[20] Bowron D. T., G. Bushnell-Wye, R. J. Newport, B. D. Rainford, and G. A. Saunders. 1996. J. Phys.: Condensed Matter. 8: 3337.

[21] Anderson R., T. Brennan, G. Mountjoy, R. J. Newport, and G. A. Saunders. 1998. J. Non-Cryst. Solids. 232234: 286.

[22] Anderson R., T. Brennan, J. M. Cole, G. Mountjoy, R. J. Newport, and G. A. Saunders. 1999. J. Mater. Res. 14: 4706. 